\title{
PENGARUH BUDAYA KERJA, LINGKUNGAN KERJA DAN TUNJANGAN KINERJA TERHADAP KINERJA MELALUI KEPUASAN PEGAWAI PADA KANTOR KEMENTERIAN AGAMA
}

\author{
Agung Widyanarko ${ }^{1 *}$, Sukesi ${ }^{2}$ \\ ${ }^{12}$ Program Studi Magister Manajemen Fakultas Ekonomi dan Bisnis Universitas Dr. Soetomo Surabaya \\ *Penulis Korespondensi; ${ }^{1}$ agungwidyanarko82@gmail.com
}

\begin{abstract}
The purpose of this study was to analyze the influence of work culture, work environment and performance benefits on job satisfaction and employee performance at the Mojokerto Regency Ministry of Religion Office. This type of research used quantitative research. This study used saturated sampling (census) so that the number of respondents was 55 people. The analysis technique used is structural equation modeling analysis with Smart PLS statistical tools. The results showed that work culture and performance benefits were statistically proven to have an influence on employee satisfaction. While the work environment did not have a significant effect on employee satisfaction at the Mojokerto Regency Ministry of Religion Office. Work culture, work environment and performance benefits were statistically proven to have a significant influence on employee performance. Employee job satisfaction was statistically proven to have a significant effect on employee performance at the Mojokerto Regency Ministry of Religion Office.
\end{abstract}

Keywords: Work culture, work environment, work benefits.

\section{Pendahuluan}

Keberhasilan pencapaian visi dan misi organisasi sangat ditentukan oleh kinerja individu pegawai. Setiap organisasi atau perusahaan dituntut untuk selalu meningkatkan kinerja sumber daya manusianya demi tercapainya tujuan organisasi. Kinerja seseorang merupakan kombinasi dari motivasi, kemampuan, usaha dan kesempatan untuk menyelesaikan tugas atau pekerjaan seseorang berdasarkan derajat kesediaan dan tingkat kemampuan pegawai yang dapat dinilai dari hasil kerjanya.

Budaya kerja sebaiknya dimiliki oleh perusahaan termasuk instansi pemerintah agar pegawai memiliki nilai-nilai, norma, acuan, pedoman yang harus dilaksanakan. Budaya organisasi juga sebagai pemersatu pegawai, peredam konflik dan motivasi pegawai untuk melaksanakan tugas dengan baik, sehingga berpengaruh positif terhadap perilaku dan kinerja pegawai. Budaya kerja pada umumnya merupakan pernyataan filosofis, dapat difungsikan sebagai tuntutan yang mengikat para karyawan karena dapat diformulasikan secara formal dalam berbagai peraturan dan ketentuan perusahaan (Moeljono, 2005). Jika dikaitkan dengan organisasi, khususnya di Kementerian Agama Kabupaten Mojokerto, maka budaya kerja menunjukkan bagaimana nilai-nilai budaya kerja diinternalisasikan dengan menggunakan sarana (vehicle) tertentu, sehingga masyarakat dapat merasakan pelayanan yang prima (excellent service) dari organisasi pemerintah Kementerian Agama Kabupaten Mojokerto. Hal itu seperti hasil penelitian dari Widiastuti dan Rahim (2014) bahwa budaya kerja, kompensasi dan kepemimpinan berpengaruh terhadap kinerja Pegawai Negeri Sipil Badan Perencanaan Pembangunan Daerah Kota Kendari Tahun 2013. Demikian halnya dengan hasil penelitian Saleha (2016) menunjukkan bahwa lingkungan kerja, etos kerja, dan budaya kerja secara simultan dan parsial berpengaruh signifikan terhadap kinerja karyawan di Bina Marga Agency Centra Sulawesi.

Lingkungan kerja dapat menciptakan hubungan kerja yang mengikat antara orang-orang yang ada di dalam lingkungannya. Lingkungan kerja menurut Sutrisno (2010) adalah keseluruhan sarana dan prasarana kerja yang ada di sekitar karyawan yang sedang melakukan pekerjaan yang dapat mempengaruhi pelaksanaan pekerjaan. Nitisemito (dalam Yasa \& Utama, 2014) menyatakan bahwa ling- 
kungan kerja merupakan kondisi dari segala sesuatu yang terdapat di sekitar tempat bekerja karyawan yang mampu memberikan pengaruh bagi dirinya dalam melaksanakan pekerjaannya. Oleh karena itu, hendaknya diusahakan agar lingkungan kerja harus baik dan kondusif menjadikan karyawan merasa nyaman berada di ruangan dan merasa senang serta bersemangat untuk melaksanakan setiap tugastugasnya. Menurut hasil penelitian Leblebici (2012) menjelaskan tentang perilaku karyawan di lingkungan kerja memiliki pengaruh yang tinggi terhadap produktivitas. Hasil penelitian ini menyatakan bahwa komponen perilaku dari lingkungan kerja memiliki pengaruh yang lebih tinggi terhadap produktivitas, dibandingkan dengan pengaruh komponen fisik. Hasil penelitian Suwondo dan Sutanto (2015) menunjukkan bahwa secara individual dan secara bersama-sama lingkungan kerja dan disiplin kerja berpengaruh terhadap kinerja karyawan Bank di kota Malang.

Tunjangan kinerja atau dengan kata lain remunerasi telah mendapat persetujuan dari Presiden Republik Indonesia. Adapun aturan yang berkaitan dengan tunjangan kinerja pegawai negeri sipil ini di Kementerian Agama adalah Peraturan Presiden Nomor 108 Tahun 2014 dan diganti dengan Peraturan Presiden Nomor 154 Tahun 2015. Tujuan atau manfaat diberikannya tunjangan kinerja atau remunerasi bagi pegawai negeri sipil ini adalah mendorong agar pegawai negeri sipil menjadi sumber daya manusia yang berkualitas. Menurut hasil penelitian Andisi dan Uhing (2018) menunjukan bahwa tunjangan kinerja daerah, kompensasi dan jaminan sosial berpengaruh terhadap produktivitas kerja pegawai pada dinas energi dan sumber daya mineral daerah provinsi Sulawesi Utara. Hasil peneitian Sutanto (2003) menunjukan bahwa seluruh tenaga penjual merasa puas karena perusahaan memberikan kompensasi yang adil. Di samping itu, keadilan kompensasi memiliki hubungan dengan prestasi tenaga penjual. Tenaga penjual yang memandang adil atas kompensasi yang diberikan perusahaan dapat mempengaruhi tenaga penjual tersebut dalam bekerja, mereka akan lebih berusaha meningkatkan prestasinya dengan harapan memperoleh tambahan kompensasi mengingat perusahaan memberikan kompensasi terutama yang berupa komisi kepada tenaga penjual berdasarkan prestasi.

Oleh karena itu, Kantor Kementerian Agama Kabupaten Mojokerto sangat membutuhkan karyawan/pegawai yang memiliki kuantitas dan kulitas yang sangat baik, sebab tugas dan kewajiban yang perlu dipertanggungjawabkan oleh Kementerian Agama Kabupaten Mojokerto bukan suatu perkara yang mudah, maka dari itu kinerja pegawai yang mempunyai komitmen yang tinggi dalam menjalankan tugasnya, dituntut kreatif, inovatif serta mampu efektif dalam melakukan tugasnya. Namun dalam kenyataannya para pegawai tidak sesempurna yang diharapkan oleh institusi dan pimpinan yang sebagaimana orang yang menjalankan roda organisasi tersebut, bisa dilihat didata absensi pegawai Kantor Kementerian Agama Kabupaten Mojokerto selama tiga tahun terakhir sebagaimana terlihat pada Tabel 1.

Tabel 1

Rekapitulasi Absensi Pegawai Kantor Kementerian Agama Kabupaten Mojokerto Tahun 2016 s/d 2018

\begin{tabular}{lccc}
\hline \multicolumn{1}{c}{ Kriteria } & \multicolumn{3}{c}{ Tahun } \\
\cline { 2 - 4 } & 2016 & 2017 & 2018 \\
\hline Sakit & 8 & 10 & 15 \\
Izin & 29 & 40 & 32 \\
Cuti & 20 & 25 & 29 \\
Tanpa keterangan & 3 & 5 & 8 \\
Jumlah hari absen & 60 & 80 & 84 \\
Jumlah hari kerja & 26 & 261 & 261 \\
Persentase (\%) & $22,99 \%$ & $30,65 \%$ & $32,18 \%$ \\
\hline
\end{tabular}

Berdasarkan Tabel 1 diketahui bahwa tingkat kehadiran kerja pegawai di kantor Kementerian Negeri Agama Kabupaten Mojokerto 23\% di tahun 2016, sedangkan pada tahun 2017 meningkat menjadi 30,65\% dan mengalami peningkatan kembali pada tahun 2018 sebesar 32,18\%. Hal ini menunjukkan bahwa semakin meningkat persentase ketidakhadiran pegawai mengindikasikan maka kinerja pegawai yang semakin menurun.

Tujuan dari penelitian ini, antara lain: Menganalisis pengaruh budaya kerja, lingkungan kerja dan tunjangan kinerja terhadap kinerja; Menganalisis pengaruh budaya kerja, lingkungan kerja dan tunjangan kinerja terhadap kepuasan; Menganalisis pengaruh kepuasan kerja terhadap kinerja; Menganalisis pengaruh budaya kerja terhadap kinerja melalui kepuasan; Menganalisis pengaruh 
lingkungan kerja terhadap kinerja melalui kepuasan; Menganalisis pengaruh tunjangan kinerja terhadap kinerja melalui kepuasan; Menganalisis budaya kerja, lingkungan kerja dan tunjangan kinerja memiliki pengaruh secara tidak langsung terhadap kinerja melalui kepuasan pegawai di Kantor Kementerian Agama Kabupaten Mojokerto.

\section{Kajian Teoritis dan Hipotesis}

Keberhasilan suatu organisasi akan tercapai dipengaruhi oleh beberapa faktor dalam bekerja, ada banyak faktor yang mempengaruhi, namun dalam penelitian ini hanya beberapa faktor yang diangkat di antaranya budaya kerja, lingkungan kerja dan tunjangan kinerja.

\section{Budaya Kerja}

Budaya kerja adalah sikap pegawai terhadap pekerjaan dan perilaku pegawai pada waktu bekerja. Definisi konseptual ini diturunkan menjadi dua dimensi kajian yaitu dimensi sikap pegawai terhadap pekerjaan dan dimensi perilaku pegawai pada waktu bekerja. Lingkungan yang berbeda akan memberi dampak pada pola dan warna budaya, karena itu terjadi pola dan warna budaya yang tebal dan tipis. Faktor-faktor yang mempengaruhi budaya kerja adalah kebersamaan dan intesitas. Budaya kerja adalah suatu falsafah yang didasari oleh pandangan hidup sebagai nilai-nilai yang menjadi sifat, kebiasaan dan kekuatan pendorong yang telah membudaya dalam kehidupan suatu organisasi atau pemerintahan. Oleh sebab itu, budaya kerja bisa diukur dengan sikap pegawai terhadap pekerjaan memiliki indikator-indikator:

a. Mau menerima arahan pimpinan

b. Senang menerima tanggung jawab kerja

c. Kerja sebagai ibadah

d. Melaksanakan pekerjaan sesuai tugas

e. Dapat mengatasi kendala kerja

f. Dapat menyusun laporan kerja

Dimensi perilaku kerja pegawai pada waktu bekerja memiliki indikator:
a. Disiplin kerja
b. Jujur dalam kerja
c. Komitmen kerja
d. Tanggungjawab terhadap pekerjaan
e. Kerjasama dengan rekan kerja
f. Mengevaluasi pekerjaan

\section{Lingkungan Kerja}

Selain budaya kerja, lingkungan kerja fisik juga memiliki pengaruh. Lingkungan kerja adalah semua keadaan berbentuk fisik yang terdapat di sekitar tempat kerja yang dapat mempengaruhi karyawan baik secara langsung maupun secara tidak langsung (Sedarmayanti, 2009). Lebih jelas menurut (Suwondo \& Sutanto, 2015), lingkungan kerja fisik dibagi menjadi dua kategori, yaitu lingkungan yang berhubungan langsung dan berada di dekat karyawan (kursi, meja dan sebagainya) dan lingkungan perantara (temperatur, kelembaban, sirkulasi udara, pencahayaan, getaran mekanis, bau tidak sedap, warna dan sebagainya). Menurut Nitisemito (2006) lingkungan kerja fisik diukur melalui:
a. Suasana kerja
b. Hubungan dengan rekan sekerja
c. Tersedianya fasilitas bekerja

\section{Tunjangan Kinerja}

Menurut Subekhi dan Jauhar (2012) bentuk kompensasi berupa tunjangan, yang pada umumnya tidak dikaitkan dengan prestasi kerja. Tunjangan lebih banyak dikaitkan dengan pemberian kesempatan kesejahteraan dan penciptaan kondisi kerja, sehingga pekerja menjadi lebih merasa nyaman dan merasa mendapat perhatian atasan. Tunjangan kinerja merupakan penghasilan selain gaji yang diberikan kepada karyawan yang aktif berdasarkan kompetensi dan kinerja. Pemberian tunjangan kinerja menurut Peraturan Pemerintah Nomor 74 tahun 2015 tentang perubahan atas Peraturan Pemerintah 
Nomor 23 tahun 2005 tentang pengelolaan keuangan badan layanan umum menyebutkan bahwa tunjangan kinerja diberikan kepada pegawai negeri sipil, calon pegawai negeri sipil, menteri dan staf ahli. Menurut Mangkunegara (2010), ada beberapa indikator tunjangan kerja, yaitu:
a. Tingkat bayaran
b. Struktur pembayaran
c. Penentuan bayaran individu
d. Metode pembayaran
e. Kontrol pembayaran

\section{Kinerja Pegawai}

Kinerja (performance) berasal dari akar kata 'to perform' yang mempunyai beberapa pengertian yaitu melakukan, melaksanakan, dan melakukan sesuatu yang diharapkan seseorang, dikutip oleh Sedarmayanti (2009). Arti kata performace merupakan kata benda (noun) yang memiliki arti pembuatan, pelaksanaan kerja, prestasi kerja, dan pelaksanaan pekerjaan yang berdaya guna. Menurut Rivai (2004) mengemukakan beberapa pengertian kinerja yaitu: "Kinerja merupakan seperangkat hasil yang dicapai dan merujuk pada tindakan pencapaian serta pelaksanaan sesuatu pekerjaan yang diminta". Menurut Simamora (2004), kinerja adalah "hasil kerja karyawan terhadap kontribusinya kepada organisasi selama periode waktu tertentu". Menurut Sutrisno (2010), kinerja adalah "hasil kerja yang telah dicapai seseorang dari tingkah laku kerjanya dalam melaksanakan aktivitas kerja". Menurut Mangkunegara (2010), kinerja adalah "hasil kerja secara kualitas dan kuantitas yang dicapai oleh seseorang pegawai dalam melaksanakan tugasnya sesuai dengan tanggungjawab yang diberikan kepadanya". Kinerja menurut Wibowo (2016) adalah hasil kerja secara kualitas dan kuantitas yang di capai seorang pegawai dalam melaksanakan tugasnya sesuai dengan tanggung jawab yang di berikan kepadanya. Indikator kinerja meliputi:

a. Tepat/Jelas (transparan)

b. Fokus pada target

c. Ketepatan waktu

d. Kerjasama tim

e. Memenuhi kualitas dan kuantitas

\section{Kepuasan Kerja}

Kepuasan kerja merupakan suatu sikap umum terhadap pekerjaan seseorang, selisih antara banyaknya ganjaran yang diterima seorang pekerja dan banyaknya yang diyakini seharusnya mereka terima. Seseorang dengan tingkat kepuasan kerja tinggi menunjukan sikap yang positif terhadap suatu pekerjaan. Menurut Siagian (2013) pembahasan mengenai kepuasan kerja perlu didahului oleh penegasan bahwa masalah kepuasan kerja bukanlah hal yang sederhana, baik dalam arti konsepnya maupun dalam arti analisisnya, karena "kepuasan" mempunyai konotasi yang beraneka ragam. Ketidakpuasan dalam memperoleh imbalan mempengaruhi perasaan individu melalui dua cara. Pertama, meningkatnya keinginan untuk mendapatkan penghasilan yang lebih banyak. Misalnya bekerja lebih baik, atau mencari pekerjaan lain. Kedua, menurunnya daya tarik pekerjaan. Jika pekerjaan kehilangan daya tariknya, karyawan cenderung akan absen, sulit diatur, dan menjadi tidak puas dengan pekerjaan itu sendiri. Kepuasan gaji pada umumnya mempunyai pengaruh yang cukup signifikan pada kinerja karyawan maupun organisasi. Beberapa definisi di atas umumnya menyatakan bahwa kepuasan kerja merupakan bentuk perasaan atau emosional seseorang terhadap pekerjaannya, situasi kerja, lingkungan kerja, dan rekan sekerja. Oleh sebab itu, kepuasan kerja merupakan sesuatu yang penting untuk dimiliki oleh seseorang. Pekerja dapat berinteraksi dengan lingkungan kerjanya. Untuk selanjutnya mereka akan bekerja sebaik mungkin, sehingga tujuan perusahaan akan tercapai. Kepuasan kerja menurut Robbins (2012) kepuasan kerja sebagai suatu sikap umum terhadap pekerjaan seseorang, selisih antara seberapa banyak ganjaran yang diterima seorang pekerja dan seberapa banyak yang diyakini haruslah diterima. Indikator kepuasan kerja meliputi:

a. Pekerjaan itu sendiri

b. Gaji promosi

c. Supervisi 
Berdasarkan penjelasan di atas maka kerangka pemikiran dari penelitian ini diuraikan sebagai berikut:

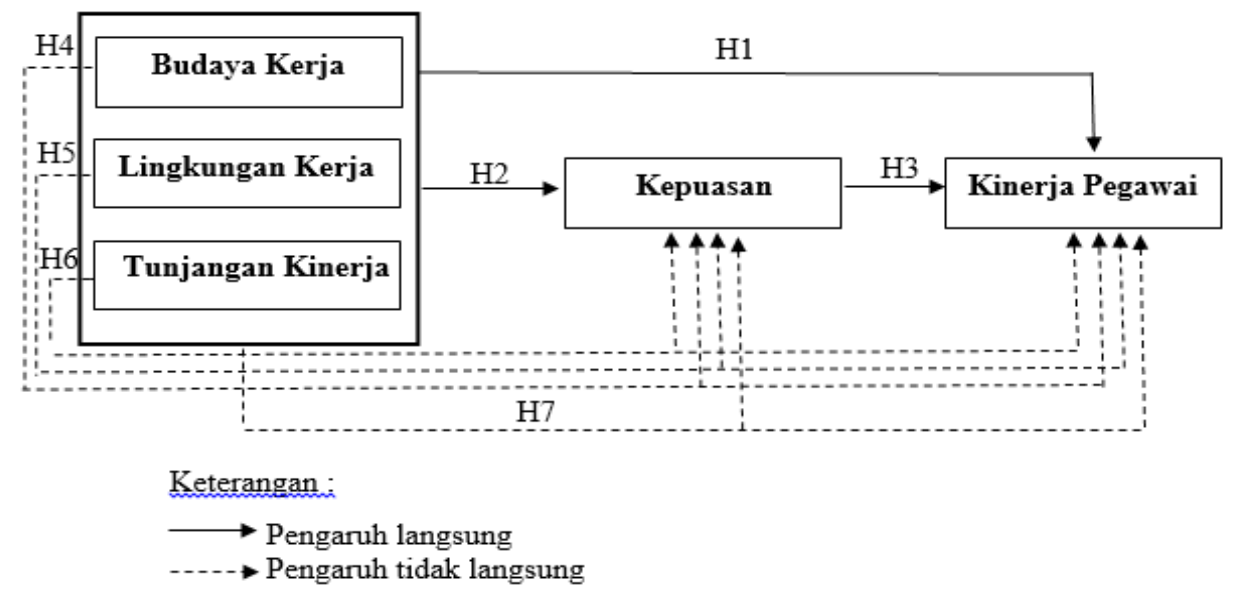

\section{Gambar 1. Kerangka pemikiran}

Oleh karena itu, diajukan hipotesisnya sebagai berikut:

$H_{l}$ : Budaya kerja, lingkungan kerja dan tunjangan kinerja memiliki pengaruh langsung terhadap kinerja pegawai di Kantor Kementerian Agama Kabupaten Mojokerto.

$H_{2}$ : Budaya kerja, lingkungan kerja dan tunjangan kinerja memiliki pengaruh langsung terhadap kepuasan kerja pegawai di Kantor Kementerian Agama Kabupaten Mojokerto.

$H_{3}$ : Kepuasan kerja memiliki pengaruh langsung terhadap kinerja pegawai di Kantor Kementerian Agama Kabupaten Mojokerto.

$H_{4}$ : Budaya kerja memiliki pengaruh secara tidak langsung terhadap kinerja pegawai melalui kepuasan pegawai di Kantor Kementerian Agama Kabupaten Mojokerto.

$H_{5}$ : Lingkungan kerja memiliki pengaruh secara tidak langsung terhadap kinerja pegawai melalui kepuasan pegawai di Kantor Kementerian Agama Kabupaten Mojokerto.

$H_{6}$ : Tunjangan kinerja memiliki pengaruh secara tidak langsung terhadap kinerja pegawai melalui kepuasan pegawai di Kantor Kementerian Agama Kabupaten Mojokerto.

$H_{7}$ : Budaya kerja, lingkungan kerja dan tunjangan kinerja memiliki pengaruh secara tidak langsung terhadap kinerja melalui kepuasan pegawai di Kantor Kementerian Agama Kabupaten Mojokerto.

\section{Metode Penelitian \\ Populasi dan Sampel}

Populasi dalam penelitian ini adalah seluruh pegawai yang ada di kantor Kementerian Agama Kabupaten Mojokerto yang beralamat di jalan R.A. Basuni Nomor 28A Sooko Kabupaten Mojokerto yang berjumlah 70 pegawai (55 PNS dan 15 Honorer). Dalam penelitian ini pegawai yang diambil sebagai sumber informasi adalah hanya karyawan yang sudah PNS. Oleh sebab itu, digunakan sampling jenuh untuk menentukan jumlah sampel, sehingga jumlah sampel yang dipakai dalam penelitian ini adalah 55 orang.

\section{Definisi Operasional Variabel}

Definisi operasional variabel penelitian yaitu masing-masing variabel yang digunakan di dalam penelitian didefinisikan secara jelas agar dapat diukur dengan mengunakan alat ukur yaitu skala likert, sehingga, definisi operasional variabel dapat diuraikan pada Tabel 2.

\section{Ruang Lingkup Penelitian}

Pendekatan yang digunakan dalam penelitian ini adalah pendekatan kuantitatif. Metode survei digunakan dalam evaluasi program dengan maksud menjajagi, mengumpulkan, menggambarkan dan 
menerangkan aspek-aspek yang dievaluasi. Kegiatan menjajagi, mengumpulkan dan menggambarkan data, berguna mengungkap situasi atau peristiwa dari akumulasi informasi yang deskriptif. Variabelvariabel yang akan diteliti dan dianalisis dalam penelitian ini adalah sebagai berikut:

a. Variabel bebas, terdiri atas budaya kerja $\left(X_{1}\right)$ dan lingkungan kerja $\left(X_{2}\right)$.

b. Variabel terikat, yaitu kinerja pegawai Kementerian Agama Kabupaten Mojokerto $(Y)$.

c. Variabel intervening, yaitu kepuasan $(Z)$.

Tabel 2

Definisi Operasional Variabel

\begin{tabular}{l} 
Definisi Variabel \\
\hline Budaya kerja $\left(X_{I}\right)$ merupakan pernyataan filosofis, \\
dapat difungsikan sebagai tuntutan yang mengikat \\
para karyawan karena dapat diformulasikan secara \\
formal dalam bebagai peratuan dan ketentuan \\
perusahaan (Moeljono, 2005).
\end{tabular}

Lingkungan kerja $\left(X_{2}\right)$ kondisi tempat kerja yang baik, sehingga dapat membuat pegawai merasa menyenangkan, aman, tenteram, dan perasaan betah dalam bekerja (Sedarmayanti, 2009).

Tunjangan kinerja $\left(X_{3}\right)$, adalah bentuk kompensasi berupa tunjangan, yang pada umumnya tidak dikaitkan dengan prestasi kerja (Subekhi \& Jauhar, 2012).
a. Kebiasaan
b. Dedikasi
c. Respon terhadap lingkungan

Lingkungan kerja fisik:

a. Ketenangan bekerja

b. Kondisi ruang kerja

c. Perlengkapan kerja

Lingkungan kerja non fisik:

a. Hubungan dengan pimpinan dan rekan kerja

b. Kesempatan berprestasi

c. Komunikasi dengan pimpinan maupun rekan kerja

a. Tingkat bayaran

b. Struktur Pembayaran

c. Penentuan Bayaran Individu

d. Metode Pembayaran

e. Kontrol Pembayaran

a. Pekerjaan itu sendiri

b. Kepuasan dalam bekerja

Kepuasan kerja menurut Robbins (2012) kepuasan

c. Gaji yang di terima kerja sebagai suatu sikap umum terhadap pekerjaan seseorang, selisih antara seberapa banyak ganjaran yang diterima seorang pekerja dan seberapa banyak yang diyakini haruslah diterima.

d. Kompensasi

e. Promosi jabatan

f. Diklat peningkatan kompetensi

g. Bimbingan atau arahan dari atasan

h. Komunikasi atasan dan bawahan
a. Tepat/Jelas (transparan)
b. Komunikasi dengan atasan
c. Sesuai target
d. Perencanaan yang baik
e. Ketepatan waktu
f. Disiplin waktu
g. Kerja sama tim
h. Kerjasama yang baik
i. Memenuhi kualitas dan kuantitas
j. Kompeten dalam bekerja

\section{Jenis dan Sumber Data}

Metode pengumpulan data dalam penelitian ini berdasarkan derajat sumbernya dapat dikelompokkan menjadi dua yaitu data primer dan data sekunder. 


\section{Teknik Pengumpulan Data dan Teknik Analisis}

Metode pengumpulan data yang dilakukan dalam penelitian ini yaitu dengan menggunakan $\mathrm{Ku}$ esioner, sedangkan teknik analisis yang dipakai dalam penelitian ini terdiri atas: Metode statistik deskriptif dan analisis statistik inferensial (uji validasi, uji reliabilitas, analisis partial least square (PLS), dan uji hipotesis).

\section{Analisis Data dan Pembahasan \\ Analisis Deskriptif}

Berdasarkan jenis kelamin responden dapat dijelaskan melalui Tabel 3. Gambaran yang terlihat pada Tabel 3 menunjukkan bahwa responden yang berjenis kelamin pria memiliki jumlah 34 responden, sedangkan responden yang berjenis kelamin wanita sebanyak 21 responden.

Tabel 3

Karakteristik Responden Berdasarkan Jenis Kelamin

\begin{tabular}{ccc}
\hline Jenis Kelamin & Responden & Persentase \\
\hline Pria & 34 & $61,8 \%$ \\
Wanita & 21 & $38,2 \%$ \\
Total & 55 & $100 \%$ \\
\hline
\end{tabular}

Perkembangan deskripsi data usia responden dalam penelitian ini dapat dijelaskan melalui Tabel 4. Gambaran yang terlihat pada Tabel 4 menunjukkan bahwa responden yang berusia 31-55 tahun memiliki jumlah yang paling besar yaitu sebanyak 31 orang, selanjutnya usia responden antara 21-30 tahun sebanyak 24 orang, tidak ada responden yang berusia 18-20 tahun.

Tabel 4

Karakteristik Responden Berdasarkan Usia

\begin{tabular}{ccc}
\hline Usia & Responden & Persentase \\
\hline $18-20$ th & - & - \\
$21-30$ th & 24 & $43,6 \%$ \\
$31-55$ th & 31 & $56,4 \%$ \\
Total & 55 & $100 \%$ \\
\hline
\end{tabular}

Perkembangan deskripsi data responden berdasarkan tingkat pendidikan dalam penelitian ini dapat dijelaskan melalui Tabel 5. Berdasarkan Tabel 5 menunjukkan bahwa responden yang berpendidikan sarjana strata satu jumlahnya yang paling besar yaitu sebanyak 39 orang, selanjutnya pendidikan responden yang SLTA sederajat sebanyak empat orang, pendidikan responden strata dua sebanyak 12 orang.

Tabel 5

Karakteristik Responden Berdasarkan Pendidikan

\begin{tabular}{ccc}
\hline Pendidikan & Responden & Persentase \\
\hline SD & - & - \\
SMP & - & - \\
SMA & 4 & $7,3 \%$ \\
S1 & 39 & $70,9 \%$ \\
S2 & 12 & $21,8 \%$ \\
S3 & - & - \\
Total & 55 & $100 \%$ \\
\hline
\end{tabular}

\section{Analisis Data dan Pembahasan \\ Hasil Uji Convergent Validity}

Berikut adalah hasil nilai outer loading dari masing-masing indikator hasil reduksi pada variabel penelitian seperti dalam Tabel 6 . 
Tabel 6

Hasil Uji Convergent Validity

\begin{tabular}{|c|c|c|c|}
\hline Variabel & Indikator & Outer Loading & Keterangan \\
\hline \multirow{9}{*}{ Budaya kerja $\left(X_{l}\right)$} & $X_{1.1}$ & 0,705 & valid \\
\hline & $X_{1.2}$ & 0,754 & valid \\
\hline & $X_{1.3}$ & 0,816 & valid \\
\hline & $X_{1.4}$ & 0,679 & valid \\
\hline & $X_{1.6}$ & 0,817 & valid \\
\hline & $X_{1.7}$ & 0,784 & valid \\
\hline & $X_{1.8}$ & 0,798 & valid \\
\hline & $X_{1.9}$ & 0,820 & valid \\
\hline & $X_{1.10}$ & 0,641 & valid \\
\hline \multirow{4}{*}{ Lingkungan kerja $\left(X_{2}\right)$} & $X_{2.2}$ & 0,901 & valid \\
\hline & $X_{2.4}$ & 0,900 & valid \\
\hline & $X_{2.5}$ & 0,815 & valid \\
\hline & $X_{2.6}$ & 0,583 & valid \\
\hline \multirow{9}{*}{ Tunjangan kinerja $\left(X_{3}\right)$} & $X_{3.1}$ & 0,621 & valid \\
\hline & $X_{3.2}$ & 0,853 & valid \\
\hline & $X_{3.3}$ & 0,684 & valid \\
\hline & $X_{3.4}$ & 0,753 & valid \\
\hline & $X_{3.5}$ & 0,808 & valid \\
\hline & $X_{3.6}$ & 0,855 & valid \\
\hline & $X_{3.7}$ & 0,583 & valid \\
\hline & $X_{3.8}$ & 0,659 & valid \\
\hline & $X_{3.9}$ & 0,675 & valid \\
\hline \multirow{6}{*}{ Kepuasan pegawai $\left(Y_{l}\right)$} & $Y_{1.1}$ & 0,817 & valid \\
\hline & $Y_{1.2}$ & 0,810 & valid \\
\hline & $Y_{1.3}$ & 0,815 & valid \\
\hline & $Y_{1.4}$ & 0,695 & valid \\
\hline & $Y_{1.6}$ & 0,786 & valid \\
\hline & $Y_{1.7}$ & 0,536 & valid \\
\hline \multirow{8}{*}{ Kinerja Pegawai $\left(Y_{2}\right)$} & $Y_{2.1}$ & 0,726 & valid \\
\hline & $Y_{2.2}$ & 0,806 & valid \\
\hline & $Y_{2.3}$ & 0,768 & valid \\
\hline & $Y_{2.4}$ & 0,778 & valid \\
\hline & $Y_{2.5}$ & 0,721 & valid \\
\hline & $Y_{2.8}$ & 0,703 & valid \\
\hline & $Y_{2.9}$ & 0,852 & valid \\
\hline & $Y_{2.10}$ & 0,843 & valid \\
\hline
\end{tabular}

\section{Hasil Uji Descriminant Validity}

Uji discriminant validity dalam penelitian ini dengan menggunakan software PLS dengan Outer Model yaitu Convergent Validity dapat dilihat dari nilai average variance extracted (AVE) masingmasing konstruk. Yang nilainya lebih besar dari 0,5 maka dikatakan memiliki nilai discriminant validity yang baik. Hasil Uji discriminant validity terlihat pada Tabel 7.

Tabel 7

Hasil Uji Discriminant Validity

\begin{tabular}{ccc}
\hline Variabel & AVE & Keterangan \\
\hline Budaya kerja & 0,550 & valid \\
Lingkungan kerja & 0,656 & valid \\
Tunjangan kinerja & 0,529 & valid \\
Kepuasan pegawai & 0,563 & valid \\
Kinerja Pegawai & 0,603 & valid \\
\hline
\end{tabular}


Hal ini menunjukkan bahwa setiap konstruk tersebut memiliki nilai validitas yang baik dari setiap indikator nyata kuesioner yang digunakan untuk mengetahui pengaruh dimensi budaya kerja, lingkungan kerja dan tunjangan kinerja terhadap kepuasan pegawai dan kinerja pegawai Kantor Kementerian Agama Kabupaten Mojokerto dapat dikatakan valid.

\section{Hasil Uji Reliabilitas dengan Cronbach Alpha}

Hasil ini dapat menunjukkan bahwa masing-masing variabel penelitian telah memenuhi persyaratan nilai cornbach alpha, sehingga dapat disimpulkan bahwa keseluruhan variabel memiliki tingkat reliabilitas yang tinggi. Hasil uji reliabilitas terlihat dalam Tabel 8.

Tabel 8

Hasil Uji Reliabilitas dengan Cronbach Alpha

\begin{tabular}{lcc}
\hline \multicolumn{1}{c}{ Variabel } & Cronbach's Alpha & Keterangan \\
\hline Budaya kerja $\left(X_{1}\right)$ & 0,907 & Reliabel \\
Lingkungan kerja $\left(X_{2}\right)$ & 0,815 & Reliabel \\
Tunjangan kinerja $\left(X_{3}\right)$ & 0,886 & Reliabel \\
Kepuasan pegawai $\left(Y_{1}\right)$ & 0,839 & Reliabel \\
Kinerja Pegawai $\left(Y_{2}\right)$ & 0,905 & Reliabel \\
\hline
\end{tabular}

\section{Hasil Uji Path Coefficient}

Berdasarkan skema inner model yang telah ditampilkan pada Tabel 9 dapat dijelaskan bahwa nilai path coefficient terbesar ditunjukkan dengan pengaruh budaya kerja $\left(X_{I}\right)$ terhadap Kepuasan Pegawai $\left(Y_{1}\right)$ sebesar 0,475 , dan pengaruh terendah lingkungan kerja $\left(X_{2}\right)$ terhadap kepuasan pegawai $\left(Y_{1}\right)$ sebesar 0,148 .

Berdasarkan urian hasil tersebut, menunjukkan bahwa jika variabel dalam model ini memiliki path coefficient dengan angka yang positif, maka menunjukkan bahwa semakin besar nilai path coefficient pada satu variabel independen terhadap variabel dependen, maka semakin kuat pula pengaruh antar variabel independen terhadap variabel dependen tersebut dan sebaliknya.

Tabel 9

Hasil Uji Path Coefficient

\begin{tabular}{lccccc}
\hline \multicolumn{1}{c}{ Variabel } & $\begin{array}{c}\text { Budaya } \\
\text { kerja }\left(X_{1}\right)\end{array}$ & $\begin{array}{c}\text { Lingkungan } \\
\text { kerja }\left(X_{2}\right)\end{array}$ & $\begin{array}{c}\text { Kepuasan } \\
\text { pegawai }\left(Y_{1}\right)\end{array}$ & $\begin{array}{c}\text { Kinerja } \\
\text { Pegawai }\left(Y_{2}\right)\end{array}$ & Keterangan \\
\hline Budaya kerja $\left(X_{1}\right)$ & - & - & 0,475 & 0,313 & Signifikan \\
Lingkungan Kerja $\left(X_{2}\right)$ & - & - & 0,148 & 0,269 & Signifikan \\
Tunjangan Kinerja $\left(X_{3}\right)$ & - & - & 0,414 & 0,277 & Signifikan \\
Kepuasan Pegawai $\left(Y_{1}\right)$ & - & - & - & 0,242 & Signifikan \\
Kinerja Pegawai $\left(Y_{2}\right)$ & - & - & - & - & - \\
\hline
\end{tabular}

\section{Hasil Uji Kebaikan Model (Goodness of Fit)}

Berdasarkan sajian data pada Tabel 10 dapat diketahui bahwa nilai $R$ square untuk variabel Kinerja Pegawai $\left(Y_{2}\right)$ adalah 0,894, perolehan nilai tersebut menjelaskan bahwa persentase besarnya budaya kerja $\left(X_{I}\right)$ lingkungan kerja $\left(X_{2}\right)$ dan tunjangan kinerja $\left(X_{3}\right)$ serta kepuasan kerja $\left(Y_{I}\right)$ dapat dijelaskan oleh Kinerja Pegawai sebesar $89,4 \%$. Kemudian untuk nilai $R$ square yang diperoleh variabel kepuasan pegawai $\left(Y_{2}\right)$ sebesar 0,882 , perolehan nilai tersebut menjelaskan bahwa prosentase besarnya budaya kerja $\left(X_{1}\right)$ lingkungan kerja $\left(X_{2}\right)$ dan tunjangan kinerja $\left(X_{3}\right)$ dapat dijelaskan oleh kepuasan pegawai sebesar $78,2 \%$.

\section{Tabel 10}

Hasil Uji Kebaikan Model (Goodness of Fit)

\begin{tabular}{lc}
\hline \multicolumn{1}{c}{ Variabel } & Nilai $R$ square \\
\hline Kinerja Pegawai $\left(Y_{2}\right)$ & 0,894 \\
Kepuasan pegawai $\left(Y_{l}\right)$ & 0,782 \\
\hline
\end{tabular}




\section{Uji Hipotesis}

Berikut dapat dilihat secara keseluruhan korelasi setiap variabel yaitu model yang menyatakan pengaruh antara budaya kerja, lingkungan kerja terhadap kepuasan pegawai dan kinerja pegawai. Model pada Gambar 2 tidak perlu dilakukan eliminasi, hal ini disebabkan karena korelasi konstruk memiliki nilai lebih dari 0,5 .

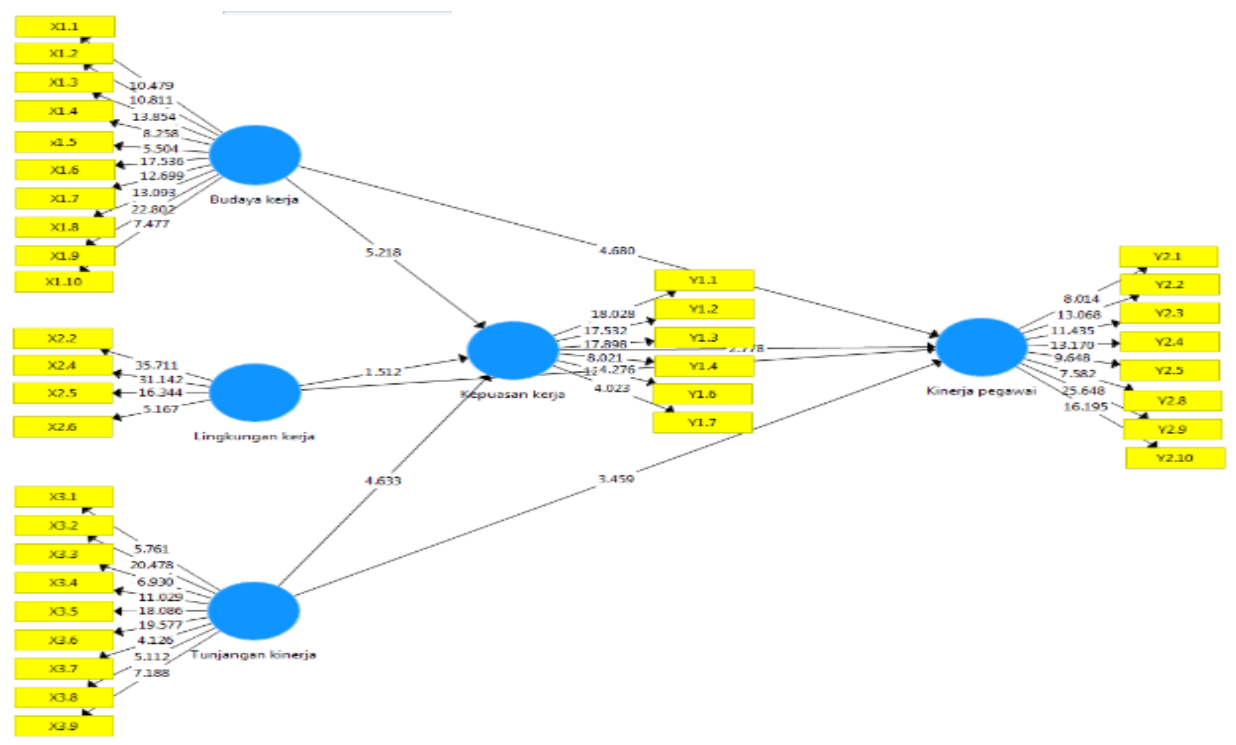

\section{Gambar 2. Model korelasi}

Dalam PLS pengujian secara statistik setiap hubungan yang dihipotesiskan dilakukan dengan menggunakan simulasi. Dalam hal ini dilakukan metode bootstrap terhadap sampel. Pengujian dengan bootstrap juga dimaksudkan untuk meminimalkan masalah ketidaknormalan data penelitian. Hasil pengujian dengan bootstrapping dari analisis PLS terlihat pada Tabel 11.

\section{Tabel 11}

Hasil Uji Kebaikan Model (Goodness of Fit)

\begin{tabular}{lccc}
\hline \multicolumn{1}{c}{ Pengaruh } & t statistics & $p$ value & Hasil \\
\hline Budaya kerja $\rightarrow$ Kinerja Pegawai & 5,168 & 0,000 & Signifikan \\
Lingkungan kerja $\rightarrow$ Kinerja Pegawai & 4,462 & 0,000 & Signifikan \\
Tunjangan kinerja $\rightarrow$ Kinerja Pegawai & 3,546 & 0,000 & Signifikan \\
Budaya kerja $\rightarrow$ Kepuasan pegawai & 5,244 & 0,000 & Signifikan \\
Lingkungan kerja $\rightarrow$ Kepuasan pegawai & 1,506 & 0,133 & Tidak Signifikan \\
Tunjangan kinerja $\rightarrow$ Kepuasan pegawai & 4,646 & 0,000 & Signifikan \\
Kepuasan pegawai $\rightarrow$ Kinerja Pegawai & 2,953 & 0,003 & Signifikan \\
$\begin{array}{l}\text { Budaya kerja } \rightarrow \text { Kepuasan Pegawai } \rightarrow \text { Kinerja pegawai } \\
\text { Lingkungan kerja } \rightarrow \text { Kepuasan pegawai } \rightarrow \text { Kinerja }\end{array}$ & 2,942 & 0,003 & Signifikan \\
pegawai & 1,173 & 0,241 & Tidak Signifikan \\
Tunjangan kinerja $\rightarrow$ Kepuasan pegawai $\rightarrow$ Kinerja & & & \\
pegawai & 2,289 & 0,023 & Signifikan \\
\hline
\end{tabular}

Hasil pengujian hipotesis model penelitian pengaruh budaya kerja, lingkungan kerja dan tunjangan kinerja terhadap kepuasan pegawai dan kinerja pegawai dengan menggunakan Smart PLS dapat dijelaskan sebagai berikut:

a. Pengujian Hipotesis 1: Pengaruh Budaya Kerja, Lingkungan Kerja dan Tunjangan Kinerja terhadap Kinerja Pegawai.

Hasil pengujian hipotesis pertama menunjukkan bahwa hubungan variabel budaya kerja, lingkungan kerja dan tunjangan kinerja dengan kinerja pegawai menunjukkan nilai koefisien jalur bernilai positif dengan nilai $t$ hitung masing-masing variabel lebih besar dari $(1,960)$ dan $p$ value sebesar 0,000 
lebih kecil dari 5\% ( $p<0,05)$. Hasil ini berarti bahwa budaya kerja, lingkungan kerjadan tunjangan kinerja memiliki hubungan yang positif dan signifikan terhadap kinerja pegawai. Hasil ini berarti bahwa budaya kerja, lingkungan kerja dan tunjangan kinerja memiliki hubungan signifikan terhadap kinerja pegawai, berarti sesuai dengan hipotesis pertama yaitu budaya kerja, lingkungan kerja dan tunjangan kinerja memiliki pengaruh terhadap kinerja pegawai. Hal ini berarti Hipotesis 1 diterima.

b. Pengujian Hipotesis 2: Pengaruh Budaya Kerja, Lingkungan Kerja dan Tunjangan Kinerja terhadap Kepuasan Pegawai.

Hasil pengujian hipotesis kedua menunjukkan bahwa hubungan variabel budaya kerja dan tunjangan kinerjadengan kepuasan pegawai menunjukkan nilai koefisien jalur bernilai positif dengan nilai $t$ hitung masing-masing variabel lebih besar dari $(1,960)$ dan $p$ value sebesar 0,000 lebih kecil dari $5 \%$ $(p<0,05)$. Hasil ini berarti bahwa budaya kerja dan tunjangan kinerja memiliki hubungan yang positif dan signifikan terhadap kepuasan pegawai. Lingkungan kerja dengan kepuasan pegawai menunjukkan nilai koefisien jalur bernilai positif dengan nilai $t$ hitung lebih kecil dari $(1,960)$ dan $p$ value sebesar 0,133 lebih besar dari $5 \%(p>0,05)$. Hasil ini berarti bahwa lingkungan kerja memiliki hubungan tidak signifikan terhadap kepuasan pegawai. Hal ini berarti tidak sesuai dengan hipotesis kedua yaitu budaya kerja, lingkungan kerja dan tunjangan kinerjamemiliki pengaruh terhadap kepuasan pegawai. Hal ini berarti Hipotesis 2 tidak diterima.

\section{c. Pengujian Hipotesis 3: Pengaruh Kepuasan Kerja terhadap Kinerja Pegawai.}

Hasil pengujian hipotesis ketiga menunjukkan bahwa hubungan variabel kepuasan kerja dengan kinerja pegawai menunjukkan nilai koefisien jalur positif dengan nilai $t$ sebesar 2,953. Nilai tersebut lebih besar dari $t$ tabel $(1,960)$ dan $p$ value sebesar 0,003 lebih kecil dari 5\% $(p<0,05)$. Hasil ini berarti bahwa kepuasan kerja memiliki hubungan yang positif dan signifikan terhadap kinerja pegawai yang berarti sesuai dengan hipotesis ketiga yaitu kepuasan kerja memiliki pengaruh terhadap kinerja pegawai. Hal ini berarti Hipotesis 3 diterima.

d. Pengujian Hipotesis 4: Pengaruh Budaya Kerja terhadap Kinerja Pegawai melalui kepuasan Pegawai.

Hasil pengujian hipotesis keempat menunjukkan bahwa hubungan variabel budaya kerja dengan kinerja pegawai melalui kepuasan pegawai menunjukkan nilai koefisien jalur sebesar 0,115 dengan nilai $t$ sebesar 2,942. Nilai tersebut lebih besar dari $t$ tabel $(1,960)$ dan $p$ value sebesar 0,003 lebih kecil dari $5 \%(p<0,05)$. Hasil ini berarti bahwa budaya kerja memiliki pengaruh tidak langsung terhadap kinerja pegawai melalui kepuasan pegawai yang berarti sesuai dengan pernyataan hipotesis keempat. Hal ini berarti Hipotesis 4 diterima.

e. Pengujian Hipotesis 5: Pengaruh Lingkungan Kerja terhadap Kinerja Pegawai melalui Kepuasan Pegawai.

Hasil pengujian hipotesis kelima menunjukkan bahwa hubungan variabel lingkungan kerja dengan kinerja pegawai melalui kepuasan pegawai menunjukkan nilai koefisien jalur sebesar 0,036 dengan nilai $t$ sebesar 1,173. Nilai tersebut lebih kecil dari t tabel $(1,960)$ dan $p$ value sebesar 0,241 lebih besar dari 5\% $(p>0,05)$. Hasil ini berarti bahwa lingkungan kerja tidak memiliki pengaruh secara tidak langsung terhadap kinerja pegawai melalui kepuasan pegawai yang berarti tidak sesuai dengan pernyataan hipotesis kelima. Hal ini berarti Hipotesis 5 tidak diterima.

f. Pengujian Hipotesis 6: Pengaruh Tunjangan Kinerja terhadap Kinerja Pegawai melalui Kepuasan Pegawai.

Hasil pengujian hipotesis keenam menunjukkan bahwa hubungan variabel tunjangan kinerja dengan kinerja pegawai melalui kepuasan pegawai menunjukkan nilai koefisien jalur sebesar 0,100 dengan nilai $t$ sebesar 2,289. Nilai tersebut lebih besar dari t tabel $(1,960)$ dan $p$ value sebesar 0,023 lebih kecil dari $5 \%(p<0,05)$. Hasil ini berarti bahwa tunjangan kinerja memiliki pengaruh tidak langsung terhadap kinerja pegawai melalui kepuasan pegawai yang berarti sesuai dengan pernyataan hipotesis keenam. Hal ini berarti Hipotesis 6 diterima. 
g. Pengujian Hipotesis 7: Budaya Kerja, Lingkungan Kerja dan Tunjangan Kinerja Memiliki Pengaruh Secara Tidak Langsung terhadap Kinerja melalui Kepuasan Pegawai.

Hasil pengujian hipotesis ketujuh menunjukkan bahwa variabel budaya kerja dan tunjangan kinerja memiliki pengaruh tidak langsung terhadap kinerja melalui kepuasan pegawai menunjukkan nilai $t$ hitung masing-masing variabel lebih besar dari $(1,960)$ dan probabilitas lebih kecil dari $5 \%$ ( $p$ < $0,05)$. Hasil ini berarti bahwa budaya kerja dan tunjangan kinerjamemiliki pengaruh tidak langsung terhadap kinerja melalui kepuasan pegawai. Pengaruh tidak langsung lingkungan kerja terhadap kinerja melalui kepuasan pegawai menunjukkan nilai $t$ hitung lebih kecil dari $(1,960)$ dan probabilitas sebesar 0,241 lebih besar dari 5\% $(p>0,05)$. Artinya bahwa lingkungan kerja memiliki hubungan tidak signifikan terhadap kinerja melalui kepuasan pegawai. Hal ini berarti tidak sesuai dengan hipotesis ketujuh yaitu budaya kerja, lingkungan kerja dan tunjangan kinerja memiliki pengaruh tidak langsung terhadap kinerja melalui kepuasan pegawai. Hal ini berarti Hipotesis 7 tidak diterima.

\section{Pembahasan}

a. Pengaruh Budaya Kerja terhadap Kinerja Pegawai pada Kantor Kementerian Agama Kabupaten Mojokerto.

Secara empiris penelitian ini telah membuktikan variabel budaya kerja memiliki pengaruh signifikan terhadap kinerja pegawai pada Kantor Kementerian Agama Kabupaten Mojokerto. Hal ini ditunjukkan dari perolehan nilai $t$ statistik sebesar 5,168 ( $p$ value $=0,000)$. Arah hubungan budaya kerja terhadap kepuasan pegawai bernilai positif, artinya perubahan variabel budaya kerja memberikan dampak pada peningkatan kinerja pegawai. Terbuktinya variabel budaya kerja berpengaruh terhadap kinerja pegawai memberikan gambaran bahwa seluruh jajaran pimpinan kantor kementerian agama khususnya di Kabupaten Mojokerto telah mampu untuk mendorong bagaimana perilaku pegawai dipandang sebagai sesuatu hal yang memiliki peranan penting dalam mencapai tujuan akhir suatu institusi. Pihak pimpinan kementerian agama kabupaten Mojokerto mendorong kerja tim, menghargai perilaku inovasi, dan menekankan inisiatif pegawai yang berkaitan dengan budaya kerja yang dikaitkan dengan kinerja pegawai. Hal ini sejalan dengan hasil penelitian dari Widiastuti dan Rahim (2014) bahwa Budaya Kerja, Kompensasi dan Kepemimpinan berpengaruh terhadap Kinerja Pegawai Negeri Sipil Badan Perencanaan Pembangunan Daerah Kota Kendari, sedangkan hasil penelitian Saleha (2016), menunjukkan bahwa lingkungan kerja, etos kerja, dan budaya kerja secara simultan dan parsial berpengaruh signifikan terhadap kinerja karyawan di Bina Marga Agency Centra Sulawesi. Hal ini menunjukan bahwa budaya kerja yang buruk akan berdampak kepada hasil kinerja yang buruk pula.

b. Pengaruh Lingkungan Kerja terhadap Kinerja Pegawai pada Kantor Kementerian Agama Kabupaten Mojokerto.

Hasil penelitian ini juga secara empiris menemukan bahwa lingkungan kerja berpengaruh signifikan terhadap kepuasan pegawai pada Kantor Kementerian Agama Kabupaten Mojokerto. Nilai $t$ statistik hubungan kedua variabel tersebut diperoleh sebesar 4,462 ( $p$ value $=0,000)$. Arah hubungan lingkungan kerja terhadap kinerja pegawai bernilai positif, artinya jika variabel lingkungan kerja berubah mengalami peningkatan maka kinerja pegawai juga akan meningkat. Hasil penelitian ini menunjukkan lingkungan kerja berpengaruh signifikan terhadap kinerja pegawai Kantor Kementerian Agama Kabupaten Mojokerto, hal ini sejalan dengn penelitian terdahulu yaitu Suwondo dan Sutanto (2015) menunjukkan bahwa secara individual dan secara bersama-sama lingkungan kerja dan disiplin kerja berpengaruh terhadap kinerja karyawan Bank di kota Malang. Menurut hasil penelitian Leblebici (2012) menjelaskan tentang perilaku karyawan di lingkungan kerja memiliki pengaruh yang tinggi terhadap produktivitas. Oleh sebab itu, dapat disimpulkan bahwa hasil pengujian yang dilakukan dalam penelitian ini terhadap variabel lingkungan kerja dan kinerja pegawai menunjukkan bahwa pada Kementerian Agama Kabupaten Mojokerto, lingkungan kerja berpengaruh signifikan terhadap kinerja pegawai, yaitu lingkungan yang nyaman menyebabkan tingkat konsentrasi pegawai dalam bekerja meningkat, dan hal ini menyebabkan meningkatnya tingkat kinerja pegawai. 
c. Pengaruh Tunjangan Kinerja terhadap Kinerja Pegawai pada Kantor Kementerian Agama Kabupaten Mojokerto

Dalam penelitian ini secara empiris terbukti bahwa variabel tunjangan kinerja berpengaruh signifikan terhadap kinerja pegawai pada Kantor Kementerian Agama Kabupaten Mojokerto. Hal ini ditunjukkan dari perolehan nilai t statistik sebesar 3,546 ( $p$ value $=0,000)$. Hubungan tunjangan kinerja terhadap kinerja pegawai bernilai positif, Jadi peningkatan perolehan tunjangan kinerja seiring dengan peningkatan kinerja pegawai di Kantor Kementerian Agama Kabupaten Mojokerto semakin besar perolehan tunjangan kinerjanya maka produktivitas atau kinerja pegawai semakin tinggi pula. Hal ini berarti tunjangan kinerja berpengaruh terhadap kinerja pegawai di Kantor Kementerian Agama Kabupaten Mojokerto.

Penelitian ini sejalan dengan penelitian Andisi dan Uhing (2018), yang menyatakan bahwa tunjangan kinerja yang diberikan kepada para pegawai Dinas Energi Dan Sumber Daya Mineral Daerah Provinsi Sulawesi Utara memiliki pengaruh yang signifikan terhadap kinerja pegawai. Secara umum interpretasi hasil penelitian ini yaitu dengan tunjangan kinerja yang diberikan memberikan pengaruh pada kualitas hasil kerja pegawai yang sesuai dengan rencana kerja yang ditungkan dalam sasaran kerja pegawai, dan capaian kinerja pegawai yang dihasilkan jumlahnya sesuai dengan target sasaran kerja pegawai.

\section{d. Pengaruh Budaya Kerja terhadap Kepuasan Pegawai pada Kantor Kementerian Agama Kabupaten} Mojokerto

Secara empiris penelitian ini telah membuktikan variabel budaya kerja memiliki pengaruh signifikan terhadap kepuasan pegawai pada Kantor Kementerian Agama Kabupaten Mojokerto. Hal ini ditunjukkan dari perolehan nilai $t$ statistik sebesar 5,244 ( $p$ value $=0,000)$. Arah hubungan budaya kerja terhadap kepuasan pegawai bernilai positif, artinya perubahan variabel budaya kerja memberikan dampak pada peningkatan kepuasan pegawai. Hasil penelitian ini menunjukkan bahwa budaya kerja berpengaruh signifikan terhadap kepuasan pegawai pada Kantor Kementerian Agama Kabupaten Mojokerto, hal ini sejalan dengan penelitian Andisi dan Uhing (2018) yang dalam penelitiannya membuktikan adanya pengaruh antara tunjangan kinerja daerah, kompensasi dan jaminan sosial berpengaruh terhadap produktivitas kerja pegawai pada Dinas Energi dan Sumber Daya Mineral Daerah Provinsi Sulawesi Utara, sedangkan hasil penelitian hasil penelitian Sutanto (2003) menunjukan bahwa seluruh tenaga penjual merasa puas karena perusahaan memberikan kompensasi yang adil.

Hubungan yang erat budaya kerja dengan kepuasan pegawai menunjukkan bahwa upaya mewujudkan budaya kerja pada Kementerian Agama Kabupaten Mojokerto telah dilakukan dengan mengembangkan suatu perilaku yang menjadi budaya kerja organisasi yang mencerminkan budaya kedisiplinan dan keteraturan kerja yang dikomunikasikan secara tertulis dan dijadikan pegangan oleh seluruh pegawai. Budaya tersebut memiliki akar dan nilai-nilai luhur yang menjadi dasar bagi etika pengelolaan pada Kementerian Agama Kabupaten Mojokerto yang menciptakan rasa kepuasan bagi pegawai. Kedisiplinan dan keteraturan kerja merupakan kunci penting keberhasilan dalam menerapkan dan memelihara etika dalam organisasi karena dengan adanya budaya kedisiplinan dan keteraturan kerja membudaya akan dapat mengurangi perbuatan yang tidak baik atau kecurangan yang akhirnya keadilan bagi pegawai yang menjadikan mereka puas dalam bekerja.

\section{e. Pengaruh Lingkungan Kerja terhadap Kepuasan Pegawai pada Kantor Kementerian Agama Kabu- paten Mojokerto}

Hasil penelitian ini telah membuktikan bahwa variabel lingkungan kerja tidak berpengaruh signifikan terhadap kepuasan pegawai pada Kantor Kementerian Agama Kabupaten Mojokerto. Hal ini ditunjukkan dari perolehan nilai $t$ statistik sebesar 1,506 ( $p$ value $=0,133)$, sedangkan arah hubungan lingkungan kerja terhadap kepuasan pegawai bernilai positif, artinya jika variabel lingkungan kerja berubah mengalami peningkatan maka kepuasan pegawai juga akan meningkat.

Hasil penelitian ini menunjukkan lingkungan kerja tidak berpengaruh signifikan terhadap kepuasan pegawai pada Kantor Kementerian Agama Kabupaten Mojokerto, hal ini tidak sejalan dengan teori yang disampaikan oleh Sedarmayanti (2009), yang menyatakan bahwa lingkungan kerja yaitu semua keadaan yang terdapat di sekitar tempat kerja dapat mempengaruhi kepuasan karyawan. Lingku- 
ngan kerja tidak memberikan pengaruh signifikan terhadap kepuasan kerja, disebabkan kondisi lingkungan kerja tidak seluruhnya menyentuh secara langsung terhadap tingkat kepuasan pegawai. Keberadaan adanya rasa kepuasan kerja diakibatkan dari situasi kerja yang ada dalam organisasi. Namun demikian kepuasan kerja dalam masing-masing karyawan lebih bersifat dinamis, artinya dapat berubah sewaktu-waktu. Pada saat tertentu karyawan bisa saja mengalami ketidakpuasan dan sebaliknya pada saat tertentu juga pegawai merasa puas. Oleh karena itu, lingkungan kerja bukanlah faktor pententu yang selalu mampu menciptakan kepuasan kerja bagai para pegawainya. Karena kepuasan bersinggungan pula dengan berbagai macam komponen, seperti emosi dan kecenderungan perilaku seorang pegawai, perselisihan dan pertentangan yang dihadapinya.

f. Pengaruh Tunjangan Kinerja terhadap Kepuasan Pegawai pada Kantor Kementerian Agama Kabupaten Mojokerto

Hasil penelitian ini telah membuktikan bahwa variabel tunjangan kinerja berpengaruh signifikan terhadap kepuasan pegawai pada Kantor Kementerian Agama Kabupaten Mojokerto. Hal ini ditunjukkan dari perolehan nilai $t$ statistik sebesar 4,646 ( $p$ value $=0,000$ ). Hubungan tunjangan kinerja terhadap kepuasan pegawai bernilai positif, artinya jika variabel lingkungan kerja berubah mengalami peningkatan maka kepuasan pegawai juga akan meningkat.

Hasil penelitian ini menunjukkan tunjangan kinerja berpengaruh signifikan terhadap kepuasan pegawai pada Kantor Kementerian Agama Kabupaten Mojokerto, hal ini sejalan dengan penelitian Andisi dan Uhing (2018), yang menyatakan bahwa tunjangan kinerja yang diberikan kepada para pegawai Dinas Energi dan Sumber Daya Mineral Daerah Provinsi Sulawesi Utara memiliki pengaruh yang signifikan terhadap kepuasan kerja pegawai. Dari hasil penelitian ini dapat dijelaskan bahwa imbalan yang diberikan oleh kementerian agama kabupaten Mojokerto merupakan pemberian tunjangan kinerja yang menjadi sarana motivasi, dapat menjadi perangsang atau pendorong yang diberikan secara sengaja kepada para pegawai dengan maksud menumbuhkan semangat yang lebih besar untuk berprestasi bagi organisasi.

g. Pengaruh Kepuasan Pegawai terhadap Kinerja Pegawai pada Kantor Kementerian Agama Kabupaten Mojokerto

Hasil penelitian ini juga secara empiris menemukan bahwa kepuasan pegawai berpengaruh signifikan terhadap kinerja pegawai pada Kantor Kementerian Agama Kabupaten Mojokerto. Nilai $t$ statistik hubungan kedua variabel tersebut diperoleh sebesar 2,953 ( $p$ value $=0,003$ ). Arah hubungan kepuasan pegawai terhadap kinerja pegawai bernilai positif, artinya jika variabel kepuasan pegawai berubah mengalami peningkatan maka kinerja pegawai juga akan meningkat.

Hasil penelitian ini menunjukkan kepuasan pegawai berpengaruh signifikan terhadap kinerja pegawai Kantor Kementerian Agama Kabupaten Mojokerto, hal ini sejalan dengan penelitian yang dilakukan oleh Poerwangningrum dan Sudirjo (2016) yang menyatakan hasil salah satu uji hipotesisnya terbukti secara statistik kepuasan kerja memiliki pengaruh signifikan terhadap kinerja Guru SD. Hj Isriati Baiturrahman I Semarang.

Dengan tunjangan kinerja yang memadai maka pelaksanaan tugas atau pekerjaan dapat dilakukan dengan baik, cepat dan memenuhi keinginan semua pihak, baik instansi itu sendiri maupun pengguna layanan langsung yaitu masyarakat. Pemberian tunjangan kinerja merupakan penghargaan terhadap prestasi kerja pegawai. Dengan adaya penghargaan atas prestasi kerjaya itu diharapkan semangat kerja pegawai akan lebih meningkat dan produktivitas kerja meningkat pula. Kantor Kementerian Agama Kabupaten Mojokerto dalam memberikan tunjangan kinerja pegawai sudah sesuai dengan beban tugas pegawai, disiplin kerja. Hasil yang dicapai dalam hal kualitas kinerja pegawai sudah sesuai dengan tujuan kinerja artinya tingkat hasil aktivitas yang dilakukan dalam arti menyesuaikan beberapa cara ideal dari penampilan aktivitas ataupun hal utama berdasarkan target atau memenuhi tujuan-tujuan yang diharapkan berdasarkan hasil yang ingin dicapai oleh Kantor Kementerian Agama Kabupaten Mojokerto mengenai pencapaian target tugas pekerjaan yang telah diberikan terhadap masing-masing pegawai dapat dipenuhi. 


\section{Simpulan dan Saran Simpulan}

Berdasarkan hasil analisis data dan pembahasan dapat ditarik simpulan bahwa:

1. Budaya kerja, lingkungan kerja dan tunjangan kinerja memiliki pengaruh signifikan terhadap kinerja pegawai di Kantor Kementerian Agama Kabupaten Mojokerto.

2. Lingkungan kerja tidak memiliki pengaruh signifikan terhadap kepuasan pegawai di Kantor Kementerian Agama Kabupaten Mojokerto.

3. Kepuasan kerja terbukti memiliki pengaruh signifikan terhadap kinerja pegawai di Kantor Kementerian Agama Kabupaten Mojokerto.

4. Budaya kerja berpengaruh terhadap kinerja melalui kepuasan pegawai di Kantor Kementerian Agama Kabupaten Mojokerto.

5. Lingkungan kerja tidak berpengaruh terhadap kinerja melalui kepuasan pegawai di Kantor Kementerian Agama Kabupaten Mojokerto.

6. Tunjangan kinerja berpengaruh terhadap kinerja melalui kepuasan pegawai di Kantor Kementerian Agama Kabupaten Mojokerto.

7. Hasil penelitian menunjukkan budaya kerja dan tunjangan kinerja memiliki pengaruh tidak langsung terhadap kinerja melalui kepuasan pegawai, namun lingkungan kerja tidak terbukti berpengaruh terhadap kinerja melalui kepuasan pegawai.

\section{Saran}

Berdasarkan hasil penelitian ini, adapun saran yang menjadi masukan sebagai berikut:

1. Pimpinan Kantor Kementerian Agama Kabupaten Mojokerto disarankan dalam pemberian tunjangan kinerja pegawai berdasarkan evaluasi capaian kinerja pegawai. Hal ini bisa dalam bentuk catatan harian pegawai atas capaian kinerja harian yang selanjutnya dihitung bobot penilaiannya.

2. Untuk lebih meningkatnya kinerja pegawai budaya kerja pegawai harus ditingkatkan dengan cara memaksimalkan pengawasan atasan langsung, diberikan punishmen bagi yang melanggarnya, setiap bawahan yang ijin harus selektif dilihat dari sisi urjen dan tidaknya alasan tersebut.

\section{Referensi}

Andisi. C., \& Uhing, Y. (2018). Pengaruh tunjangan kinerja daerah, kompensasi dan jaminan sosial terhadap produktivitas kerja pegawai pada Dinas Energi dan Sumber Daya Mineral Daerah Provinsi Sulawesi Utara. Jurnal EMBA: Jurnal Riset Ekonomi, Manajemen, Bisnis, dan Akuntansi, 6(4), 2748-2758. https://doi.org/10.35794/emba.v6i4.21056

Leblebici, D. (2012). Impact of work place quality on employee's productivity: Case study of bank in Turkey. Journal of Business, Economics \& Finance, 1(1), 38-49.

Mangkunegara, A. A. A. P. (2010). Manajemen sumber daya manusia perusahaan. Bandung: PT Remaja Rosdakarya.

Moeljono, D. (2005). Budaya organisasi dalam tantangan. Jakarta: Elex Media Komputindo.

Nitisemito, A. (2006). Manajemen personalia: Manajemen sumber daya manusia. Jakarta: Ghalia Indonesia.

Poerwangningrum, H. E., \& Sudirjo, F. (2016). Pengaruh kepemimpinan, budaya organisasi, komitmen organisasi dan kepuasan kerja terhadap kinerja (Studi pada guru SD. Hj Isriati Baiturrahman I Semarang). Serat Acitya - Jurnal Ilmiah UNTAG Semarang, 5(1), 1-14.

Rivai, V. (2004). Manajemen sumber daya manusia untuk perusahaan. Jakarta: Raja Grafindo Persada.

Robbins, S. (2012). Perilaku organisasi. Jakarta: Penerbit Salemba Empta.

Saleha. (2016). Pengaruh lingkungan kerja, etos kerja dan budaya kerja terhadap kinerja pegawai pada Dinas Bina Marga Propinsi Sulawesi Tengah. e Jurnal Katalogis, 4(3), 196-203.

Sedarmayanti. (2009). Sumber daya manusia dan produktivitas kerja. Bandung: CV. Mandar Maju.

Siagian. (2013). Manajemen sumber daya manusia. Jakarta: Bumi Aksara.

Simamora, H. (2004). Manajemen sumber daya manusia. Yogyakarta: STIE YPKN.

Subekhi, A., \& Jauhar, M. (2012). Pengantar manajemen sumber daya manusia. Jakarta: Prestasi Pustaka. 
Sutanto, E. M. (2003). Hubungan antara temperamen karyawan, pemberian kompensasi, dan jenjang karier yang tersedia terhadap prestasi kerja karyawan. Jurnal Manajemen dan Kewirausahaan, 5(1), 42-55. https://doi.org/10.9744/jmk.5.1.pp.\%2042-55

Sutrisno. H. E. (2010). Manajemen sumber daya manusia. Jakarta: Prenada Media Group.

Suwondo, D. I., \& Sutanto, E. M. (2015). Hubungan lingkungan kerja, disiplin kerja, dan kinerja karyawan. Jurnal Manajemen dan Kewirausahaan, 17(2), 135-144. https://doi.org/10.9744/jm k.17.2.145-154

Wibowo (2016). Manajemen kinerja. Edisi Kelima. PT. Rajagrafindo. Persada Jakarta.

Widiastuti, N., \& Rahim, S. (2014). Pengaruh budaya kerja, kompensasi dan kepemimpinan terhadap kinerja pegawai negeri sipil badan perencanaan pembangunan daerah kota Kendari tahun 2013. Jurnal Kajian Bisnis, 22(1), 57-68.

Yasa, S., \& Utama, M. (2014). Pengaruh kompensasi dan lingkungan kerja terhadap kepuasaan kerja dan kinerja karyawan pada Karma Jimbaran. EJurnal Manajemen Universitas Udayana, 3(3), 609-623. 